\title{
Current Status of the Norman Site, 34WG2
}

Louis E. Vogele Jr.

U.S. Army Corps of Engineers

Follow this and additional works at: https://scholarworks.sfasu.edu/ita

Part of the American Material Culture Commons, Archaeological Anthropology Commons, Environmental Studies Commons, Other American Studies Commons, Other Arts and Humanities Commons, Other History of Art, Architecture, and Archaeology Commons, and the United States History Commons

Tell us how this article helped you.

This Article is brought to you for free and open access by the Center for Regional Heritage Research at SFA ScholarWorks. It has been accepted for inclusion in Index of Texas Archaeology: Open Access Gray Literature from the Lone Star State by an authorized editor of SFA ScholarWorks. For more information, please contact cdsscholarworks@sfasu.edu. 


\section{Current Status of the Norman Site, 34WG2}

Creative Commons License

(c) $($ i) (9)

This work is licensed under a Creative Commons Attribution-NonCommercial 4.0 International License 


\title{
CURRENT STATUS OF THE NORMAN SITE, 34WG2
}

\author{
Louis E. Vogele, Jr. \\ Archeologist \\ U.S. Army Corps of Engineers, Tulsa District
}

As defined by Finkelstein (1940) in his description of excavations at the site, the Norman site currently is completely located within the waters of Fort Gibson Reservoir, a U.S. Army Corps of Engineers (COE) lake on the Grand (Neosho) River in northeastern Oklahoma. Due to a combination of archeological excavations at the site during the 1930s and 1940s, pothunting, large-scale earthmoving activities associated with the construction of a nearby highway bridge, and approximately 50 years of wave action and seasonal inundation by Fort Gibson Reservoir, portions of Mounds I- 1 and I-2 (ed. note: Mounds $\mathrm{Ia}$ and $\mathrm{Ib}$ in the previous papers) are all that remain of the Norman site.

At normal conservation pool Mounds I-1 and $\mathrm{I}-2$ form a small island located approximately one hundred meters off shore from a popular swimming beach at Fort Gibson Reservoir. During periods of high rainfall and flooding, the mounds may be completely inundated by the lake for several weeks at a time. Based on topographic information gathered at the site in 1998, it appears that somewhere between one-third to one-half of Mounds $\mathrm{I}-1$ and $\mathrm{I}-2$ at the Norman site still remain in situ. In 1998 Mound I-1 was approximately 35 meters long, 20 meters wide, and had a maximum height of around 6 meters. Mound I-2 was much smaller, with dimensions of around 17 meters long, 8 meters wide, and 1.5 meters tall. The mounds are covered with small to medium sized pecan and cottonwood trees and a heavy undergrowth of poison ivy, sumac, and other low shrubs. The western portions of the mounds appear to be relatively undisturbed, with no visible potholes or erosion present. A large cutbank is located along much of the eastern face of the mounds, exposing up to 5 meters of Mound I-1 deposits. Personal observations of the exposed deposits at Mound I-1 during 1999 and 2000 revealed stratigraphy and features very similar to 
those recorded at other Caddoan mound sites such as the Copple Mound (34LF46) at Spiro, Mound 7 at the Harlan site (34CK6), Mound 1 at the GoforthSaindon site (3BE245), Mound A at the Huntsville site (3MA22), and Mound A at the A.C. Mackin site (41LR36). These features include compound flat topped fired clay mound surfaces, large structural pit basins, numerous burned structures, and systematic use of specific colored and textured sediments during specific mound construction events.

In recognition of the importance of what remains of the site, the Tulsa District COE has recently initiated a program to record and protect the Norman site. Beginning with efforts by former Tulsa District archeologist Frank Winchell, Tulsa District has been successful in recent years in securing limited funding to undertake basic documentation of the remaining mounds at the site. In 1998, the Tulsa District produced a contour map of Mounds I-1 and I-2. Informal consultation with interested parties, including the Oklahoma Archeological Survey, Okla- homa State Historic Preservation Office, the Caddo Tribe of Oklahoma, and Wichita and Affiliated Tribes of Oklahoma, on identifying short and long term goals for the further recording and ultimate preservation of the remaining mounds have been underway for the past two years. This consultation has recently been formalized in accordance with the 1999 revisions to the implementing regulations of the National Historic Preservation Act. In the short term, the Tulsa District plans to fund a project to record the stratigraphy visible in the cutbanks of Mounds I- 1 and I-2 and in the process hopefully secure radiocarbon and archeomagnetic samples to allow dating of some of the mound deposits. In the long term, the Tulsa District has submitted a project to Headquarters for consideration that would fund development of some permanent protection for what remains of the mounds. What that protection might ultimately entail will be contingent upon the results of the on-going consultation, the engineering requirements of potential options, and the amount of funding provided for the project.

\section{REFERENCES CITED}

Finkelstein, J. Joe

1940 The Norman Site Excavations Near Wagoner, Oklahoma. Oklahoma Prehistorian $3(3): 2-15$. 


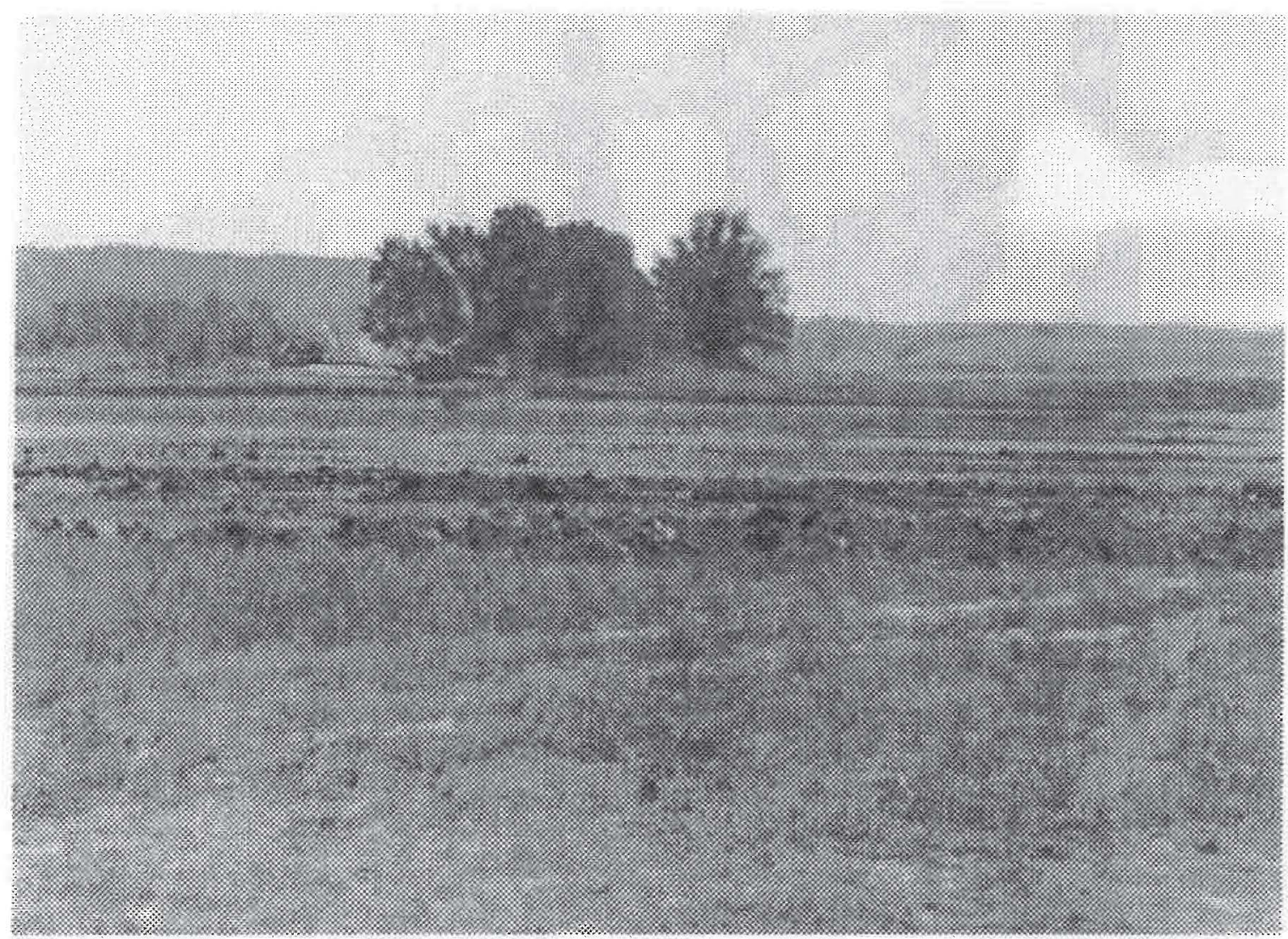

Norman site (34WG2), Wagoner County, Oklahoma, showing Mound I with partially stripped site in foreground. Photo probably by Joseph Caldwell, 1948; courtesy of the Sam Noble Oklahoma Museum of Natural History, The University of Oklahoma, Norman. 